\title{
Detection of allele specific differences in IFNL3 (IL28B) mRNA expression
}

\author{
Susanne Knapp*, Naeem Meghjee, Sorcha Cassidy, Khaleel Jamil and Mark Thursz
}

\begin{abstract}
Background: Variants of the interferon-lambda3 (IFNL3) gene have been associated with both spontaneous and treatment induced clearance of HCV infection. Attempts to link polymorphisms of the IFNL3 gene with variation in the level of IFNL3 expression have been inconclusive. This is partially due to the difficulty to design assays distinguishing IFNL3 from IFNL2.

Methods: In this study an allele specific real-time PCR (RT-PCR) assay was developed which allows the relative quantification of the two IFNL3 transcripts in cells heterozygous for SNP IFNL3.rs4803217 in the 3'UTR of the IFNL3 gene. This SNP is in strong linkage disequilibrium (LD) with the predictive marker rs 12979860.

Results: Raji cells showed two-fold increased levels of IFNL3.rs4803217 C-allele expression. In peripheral blood mononuclear cells (PBMCs) of eight uninfected donors, two donors showed increased IFNL3.rs4803217 C-allele expression.

Conclusion: This indicates that allele specific differences in IFNL3 expression vary between individuals and might contribute to the variety of outcomes in HCV infected patients.
\end{abstract}

Keywords: Variation of allele specific expression, Quantitative RT-PCR, IFNL3 gene, Hepatitis C Virus (HCV) infection, in vitro assay

\section{Background}

Recently genetic polymorphisms in the interferon-lambda3 gene (IFNL3), also known as interleukin 28B (IL-28B) have been shown to be highly associated with the outcome and treatment response of Hepatitis $\mathrm{C}$ infection in ethnically diverse cohorts [1-6]. Several single nucleotide polymorphisms (SNPs) are in linkage disequilibrium (LD), which makes the identification of the functional polymorphism challenging. Attempts have been made to link the effects of the polymorphism to a difference in the level of expression of IFNL3 transcript in vitro and in vivo [4,7] or differences in potency of the corresponding gene products [8], but no consistent difference could be detected.

The challenge with designing genotyping assays for IFNL3 is the close homology with IFNL2 (IL28A), with which it shares $96 \%$ homology on the DNA level $[4,9]$. Several IFNL3 specific TaqMan assays have been designed which discriminate IFNL3 from IFNL2 [8,10], but

\footnotetext{
*Correspondence: s.knapp@imperial.ac.uk
Imperial College, St Mary's Hospital, 10th floor QEQM Wing, Liver Unit, South
Wharf Road, London W2 1NY, UK

* Correspondence: s.knapp@@imperial.ac.uk
Imperial College, St Mary's Hospital, 10th floor QEQM Wing, Liver Unit, South
Wharf Road, London W2 1NY, UK * Correspondence: s.knapp@imperial.ac.uk
Imperial College, St Mary's Hospital, 10th floor QEQM Wing, Liver Unit, South
Wharf Road, London W2 1NY, UK
}

are not able to discriminate between the two alleles within the gene. In order to study the allele specific expression of IFNL3, we developed a SYBRGreen based RT-PCR assay which is able to quantify the two allele specific transcripts of IFNL3 (whilst excluding a signal from IFNL2) based around the two expressed alleles of the rs4803217 SNP in the 3'UTR region of IFNL3. In the Asian and Caucasian population SNP rs4803217 is in close LD with $r s 12979860\left(\mathrm{r}^{2}=0.98[11,12]\right)$, which predicts outcome of $\mathrm{HCV}$ infection and treatment response. The relative amount of allele specific transcript was measured after interferon stimulation of Huh7, Raji and Jurkat cells, and in peripheral blood mononuclear cells (PBMCs) of eight uninfected healthy donors, which were heterozygous for IFNL3.rs4803217. The assay is a modification of allele specific quantitative RT-PCR, which has been developed by Germer et al. [13] to accurately measure varying allele frequencies between $5 \%$ and $95 \%$ for SNPs in pooled DNA samples. We report that the presented IFNL3 specific assay is able to accurately measure variation of allele specific expression between individuals. 


\section{Methods}

\section{Cell lines}

The cell lines used in our experiments were Huh7, Raji and Jurkat cell lines. The Huh7 cell line is derived from hepatocellular carcinoma [14]. The Raji cell line is a suspension cell line derived from B-lymphocytes [15]. The Jurkat suspension cell line is derived from T-cells [16]. Huh7, Jurkat, Raji cells were cultivated under standard conditions in DMEM medium containing 5\% Pen/Strep and $10 \%$ heat inactivated Foetal Calf Serum (FCS) and incubated at $37^{\circ} \mathrm{C}$ under $5 \% \mathrm{CO} 2 /$ air. Confluent Huh7 and stationary phase Raji and Jurkat cells were diluted to $2 \times 10^{5}$ cells $/ \mathrm{ml}$ into $1 \mathrm{ml}$ of medium in 12 -well plates. On the following day, when the number of cells reached $4 \times 10^{5}$ cells $/ \mathrm{ml}$, cells were stimulated by adding interferon alpha (IFN $\alpha$ ) (30-2000 Units/ml; Roferon, Roche) [17], interferon beta (IFN $\beta$ ) (50-1000 Units/ml; human inter-

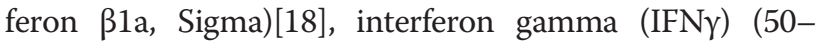
500 ng/ul; R\&D systems)[19], interferon lambda 3 (IFN入3) (IL-28B $500 \mathrm{ng} / \mathrm{ml}$; R\&D systems) [20], toll like receptor 7 (TLR7) agonist RWJ21757 (10 $\mu \mathrm{mol} ; \mathrm{R} \& \mathrm{D}$ systems) [21] or tumour necrosis factor alpha (TNF $\alpha)$ (40 ng/ $\mu \mathrm{l} ; \mathrm{R} \& \mathrm{D}$ systems) [22].

Huh7, Raji and Jurkat cells were tested for the expression of interleukin 10 receptor beta (IL1ORB), interferon alpha receptor (IFN $\alpha$ R), IFNL2/3 IL28, 2'-5'-oligoadenylate synthetase (OAS1) and myxovirus (influenza virus) resistance 1 (Mx1) (with GAPDH as a housekeeping gene) using primers published by Diegelmann et al. [23].

\section{Peripheral Blood Mononuclear cells (PBMCs)}

Peripheral blood mononuclear cells (PBMCs) from eight consented uninfected donors heterozygous for the IFNL3. rs4803217 polymorphism were isolated using HypaqueFicoll (Amersham Biosciences) density centrifugation. $1-5 \times 10^{6}$ cells in $1 \mathrm{ml}$ of medium were stimulated with 800 Units /mls IFN $\alpha$ for 6 hours.

\section{Genotyping of cell lines and healthy donors}

SYBRGreen based RT-PCR was used to characterize the genomic DNA of cell lines and uninfected donors for the IFNL3 polymorphisms rs12979860, rs8103142 and rs4803217. The schematic location of these SNPs and their pairwise linkage disequilibrium is shown in Figure 1A. Primers were designed by the author to be specific for IFNL3 and ordered from Invitrogen. Primer sequences are listed in Table 1. The position of the three primers for the $r 44803217$ RT-PCR assay within the sequence of IFNL2/3 is illustrated in Figure 1B.

Each DNA sample was interrogated twice, once with the primers specific for allele 1 (A) in combination with the common primer, then with the primer specific for

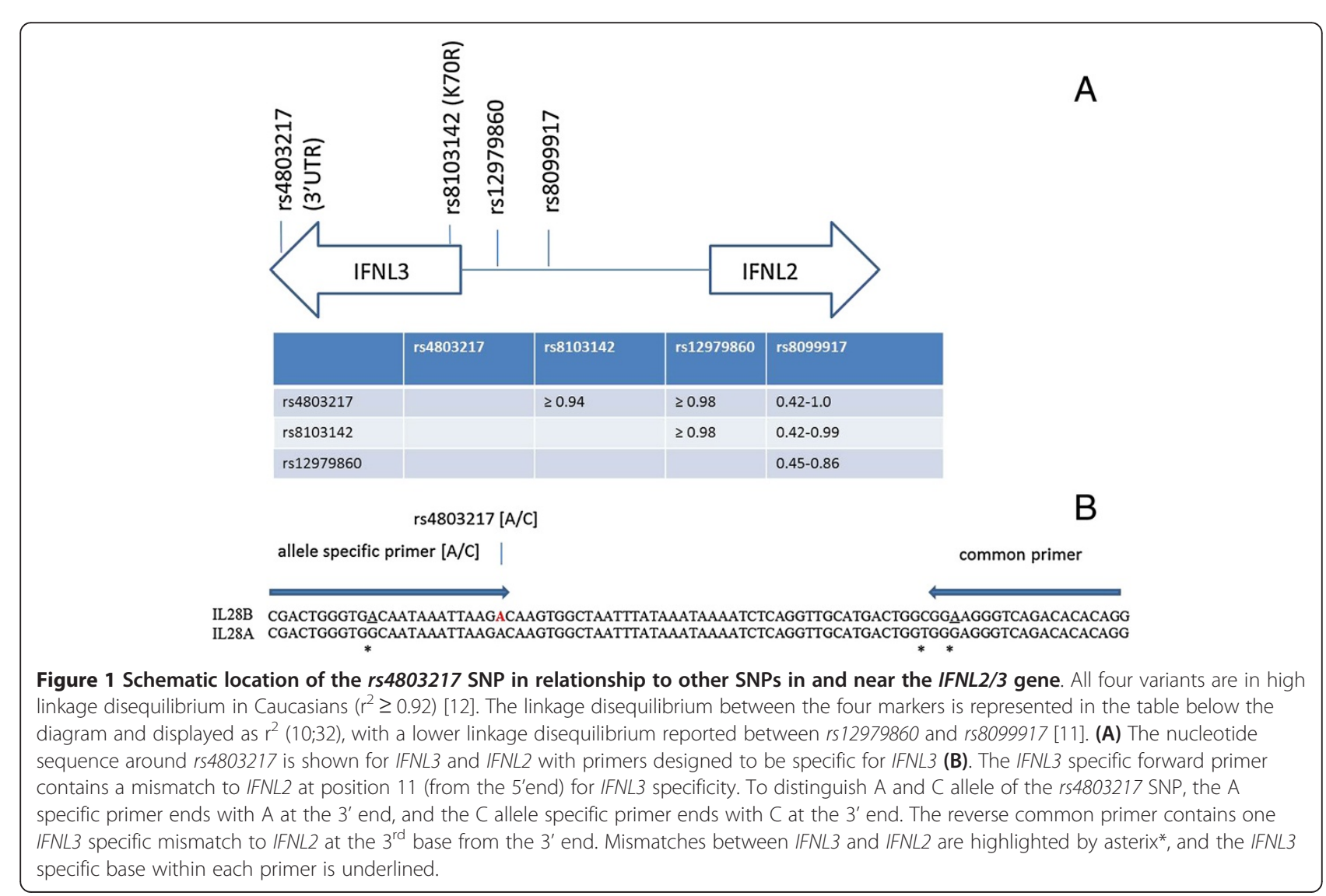


Table 1 Primer sequences for IFNL3 genotyping and expression studies

\begin{tabular}{|c|c|c|c|}
\hline SNP & Location & Allele specific primer $\left(5^{\prime}->3^{\prime}\right)$ & Common primer $\left(5^{\prime}->3^{\prime}\right)$ \\
\hline \multirow[t]{2}{*}{ rs 12979860} & $3 \mathrm{~kb}$ upstream & gcattcaaccctggttcA & gcttatcgcatacggctaggc \\
\hline & & gcattcaaccctggttcG & \\
\hline \multirow[t]{2}{*}{ rs8103142 } & exon 2 (K70R) & cttctgctgaaggactgcaA & tgagcagggctgggagg \\
\hline & & cttctgctgaaggactgcaG & \\
\hline \multirow[t]{2}{*}{ rs4803217 } & $3^{\prime} U T R$ & cgactgggtgacaataaattaagA & cctgtgtgtctgacccttcc \\
\hline & & cgactgggtgacaataaattaagC & \\
\hline
\end{tabular}

allele $2(\mathrm{C})$ in combination with the same common primer. The genotyping method using the primer combination for IFNL3.rs12979860 has been described earlier [24].

Reactions were performed in 96 well plates with $10 \mathrm{ng} / \mu \mathrm{l}$ genomic DNA and $0.5 \mu \mathrm{M}$ of each primer (one allele specific and one common primer per reaction) in the presence of a SYBRGreen containing reagent mix (QuantiTect, Qiagen) using a StepOnePlus instrument (Invitrogen). The cycling conditions were initial denaturation of $10 \mathrm{~min} 95^{\circ} \mathrm{C}, 40$ cycles of 15 seconds $95^{\circ} \mathrm{C}$ and 60 seconds $60^{\circ} \mathrm{C}$, followed by a melt curve.

Genomic DNA for the validation of the method was used as $10 \mathrm{ng} / \mathrm{ul}$ after quantification with a NanoDrop spectrophotometer (Thermo Fisher).

\section{cDNA synthesis}

RNA was extracted from cells following the RNeasy protocol (Qiagen) and from frozen PBMCs of uninfected donors using Trizol reagent (Invitrogen) in a standard protocol including DNAse treatment. cDNA was synthesized using the Retroscript kit (Ambion) according to manufacturer's instructions, but using oligo dTs and random decamers $(2.5 \mu \mathrm{M}$ each) in combination to optimize the efficiency of the cDNA synthesis. 1ug of RNA was transcribed into cDNA.

\section{Relative quantification of gene expression by real time PCR}

The same assay, including conditions and primers, which was used for genotyping was also used for relative quantification of allele specific gene expression. But in contrast to the genotyping assay, samples were run in triplicates for each allele specific reaction. $1 \mu \mathrm{l}$ of a $20 \mu \mathrm{l}$ of cDNA (cDNA from 50 ng of RNA) volume was put in each reaction. In order to use the assay for quantification of allele specific expression, the bias induced by the difference in amplification efficiency between the two allele specific reactions was corrected for by the use of a heterozygous genomic control in each experiment.

In order to validate the genotyping assay for its use in detecting potential 1.5 to 2 fold differences between the expression of the two alleles of IFNL3.rs4803217, different ratios of the two alleles from two DNAs homozygous for the respective alleles were combined and their respective
$\mathrm{dCt}$ (difference between $\mathrm{Ct}$ value of allele 1 and 2) measured using the IFNL3.rs4803217 genotyping assay. Assuming both allele specific primers have the same amplification efficiency of the assay, the reaction specific for allele1 should get amplified after the same number of amplification cycles than allele 2 , and $\mathrm{dCt}$ should be zero for a heterozygous sample carrying the same amount of allele 1 and 2. The same results (with exception of DNA measurement and pipetting errors) should be approximated if allele 1 and allele 2 are combined in a 1:1 ratio from the two homozygous DNA samples. If the alleles are present in a ratio 1:2, with allele 2 having twice the frequency of allele 1), then allele 2 should get amplified one cycle earlier (as each cycle leads to duplication of the number of amplified copies) and the $\mathrm{dCt}$ should be 1 . Therefore the relationship between ratio and $\mathrm{dCt}$ is represented by equation [1]: Ratio $=1: 2^{\mathrm{dCt}}$. Allele $1(\mathrm{~A})$ and $2(\mathrm{C})$ were combined in ratios 4:1, 3.1, 2.5:1, 2:1, 1.5:1, 1:1, 1:1.5, 1:2, 1:2.5, 1:3, 1:4.

The results were corrected with the $\mathrm{dCT}$ of the heterozygote genomic DNA control (HH23), which compensates for the difference in amplification efficiency of the two alleles. The relationship between known ratios of the two alleles and measured $\mathrm{dCt}$ values is shown in Figure 2.

The inability of the assay to discriminate against genomic DNA present in the sample is off-set by the advantage of internal validation using three sequenced genotyping controls. As the genomic DNAs of the cells tested for variation of allele specific PCR are heterozygous for the SNP which the assay is detecting, they cannot contribute to variation in allele specific expression. Therefore any observed variation (after correction for the bias introduced through unequal amplification efficiency of the two allele specific reactions which is calculated by including a genomic heterozygous control in each assay) can be attributed to a variation in allele specific expression. RNA (without reverse transcription) controls were also included in each assay in order to detect amplification resulting from genomic DNA in the cDNA.

\section{Statistical analysis}

Data were analysed using Graph Pad Prism. The MannWhitney $U$ test was applied to compare the means of the difference in allele expression between heterozygote 


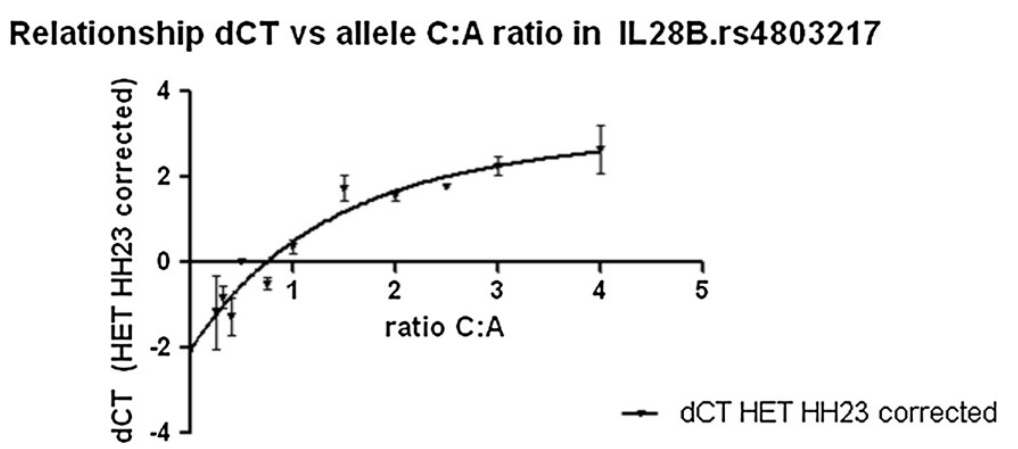

Figure 2 Relationship between dCt and varying ratios of allele 1 (allele A) and 2 (allele C) measured by the IFNL3.rs4803217 assay. The assay shows the differences in the Ct value (dCT) of the rs4803217 assay for different ratios of $\mathrm{C}$ : A allele. The differences (dCt) in the Ct value for 11 different ratios between $A$ and $C$ allele $(4: 1,3: 1,2.5: 1,2: 1,1.5: 1,1: 1,1: 1.5,1: 2,1: 2.5,1: 3,1: 4)$ is plotted after correction with the difference observed in the heterozygous genomic control $(\mathrm{HH} 23)$, where the ratio A:C is exactly 1:1. Sensitivity of IFNL3.rs4803217 assay to detect 1.5-4 fold changes in allele specific expression. Data points are the mean of triplicate reactions and error bars indicate +/- SEM.

genomic controls and cDNA in stimulated cells from four experiments in Raji cells, using three independently synthesized batches of cDNA from two independent stimulation events. Data obtained from the eight uninfected donors were analyzed in the same way. Two tailed $\mathrm{p}$-values are calculated. Data are expressed as mean + /- SEM.

\section{Results}

\section{Genotyping of cell lines and healthy donors}

The rs 4803217 RT-PCR assay is specific for IFNL3 (Figure 1B), as it distinguishes three genotypes (Figure 3). It excludes the amplification of IFNL2, which has the A allele "fixed" in the position of the rs4803217 SNP ( 3' end of the specific primer) . Cross reactivity with IFNL2 would

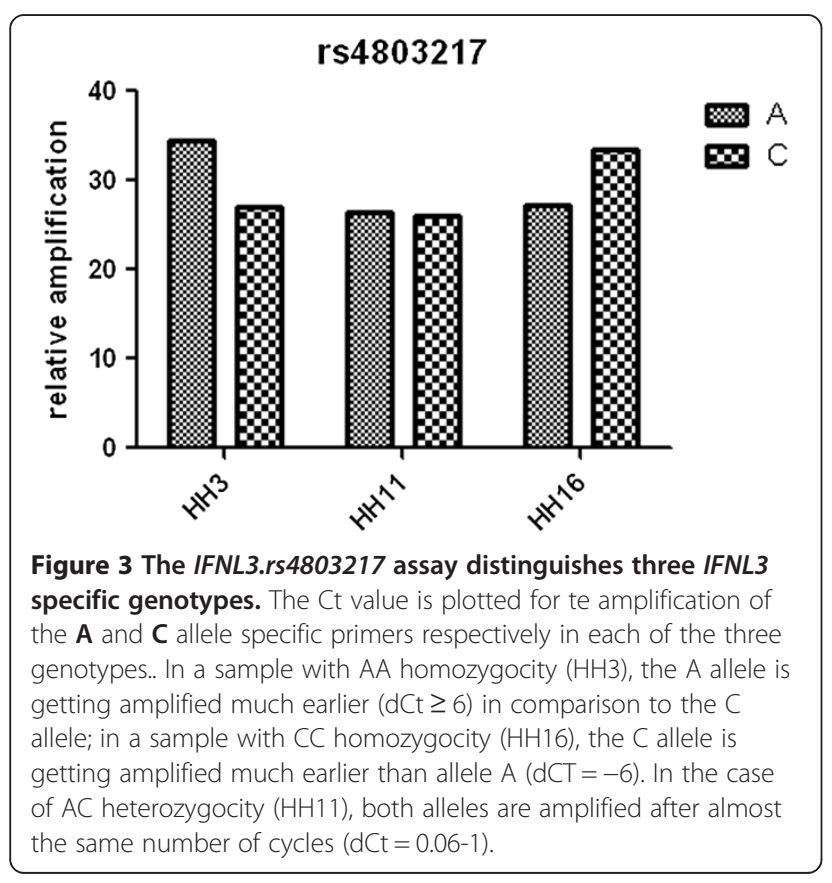

not allow the detection of $\mathrm{CC}$ homozygocity if this primer also recognized the A allele of IFNL2. The differences between the crossing points (dCt values) for the two alleles of IFNL3.rs 4803217 is robustly greater than $\mathrm{dCT}=6$ for homozygotes AA or CC in the absence of the other allele, whereas in heterozygotes the average $\mathrm{dCt}$ between the two allele specific reactions varies between 0.06 and 1 (assay variability) which is the result of the difference in amplification efficiency for the two alleles. To further confirm the IFNL3 and allele specificity of the $r s 4803217$ assay, we sequenced amplicons which suggested AA and CC homozygocity respectively from samples which had been used as controls in each assay. We confirmed that the products were IFNL3 and allele specific (Additional file 1: Figure S1: Sequence of amplification products).

Huh7, Jurkat and Raji cells are heterozygous for the IFNL3.rs12979860, IFNL3.rs8103142, and IFNL3.rs4803217 polymorphisms (Figure 1A), thus making it an ideal system for the relative comparison of the expression levels of the two alleles. RNA controls revealed that only negligible amounts of genomic DNA were present in the cDNA samples used. Eight uninfected donors heterozygous for rs4803217 were also heterozygous for rs 12979860 and rs8103142, which confirms the strong linkage disequilibrium between the three markers.

\section{Relative quantification of gene expression by real time PCR}

Huh7, Raji and Jurkat cells showed constitutive expression of ILIORB, IFN $\alpha$ R and inducible expression of IFNL2/3, $O A S 1$ and $M x 1$ (with GAPDH as a reference) after stimulation with $800 \mathrm{iU} / \mathrm{ml}$ IFN $\alpha$, indicating that the receptors for the recognition of the IFN stimulation are intact and IFNL2/3 is induced. Additional file 2: Figure S2 (induction of OAS etc after IFNa stimulation) shows the induction of $O A S$ and IFNL2/3 in Huh7 cells after 3, 6, 8, 12 and 24 hours of stimulation with $800 \mathrm{iU}$ IFNa. 
Initial dose response experiments demonstrated that induction of IFNL3 expression was optimal using $800 \mathrm{iU} / \mathrm{mls}$ IFN $\alpha$ and 6 hour incubation (see also Additional file 2: Figure S2 (gene induction)). Therefore IFNL3 expression for this manuscript was measured following this protocol. IFN $\beta$ showed the best induction after 6 hours of $500 \mathrm{iU} / \mathrm{mls}$ IFN $\beta$, and IFN $\lambda$ at $500 \mathrm{ng} / \mathrm{ml}$. Both were less efficient in the induction of IFNL3 expression and did not lead to reproducible comparisons of allele specific IFNL3 expression. Toll like receptor 7 (TLR7) agonist RWJ21757 and tumor necrosis factor alpha (TNF $\alpha)$ were unable to induce detectable levels of IFNL3 expression in Huh7 cells (data not shown) and were not tested in Raji or Jurkat cells.

As the validation experiment shows, the IFNL3.rs4803217 allele specific PCR assay is able to measure the relationship between $\mathrm{dCt}$ and 1.5-2 fold changes in the ratio of the two specific alleles (Figure 2). We therefore concluded that the assay for IFNL3.rs4803217 is suitable to measure a difference in the expression of the two alleles in cells heterozygous for the IFNL3.rs4803217 SNP.

Using the IFNL3.rs4803217 genotyping based quantitative RT-PCR assay, we detected a two-fold increased expression of IFNL3.rs4803217 C specific transcript in Raji cells in four independent experiments (fold-change 2.09 (95\% CI $=0.94-1.07)$ versus 1.01 (95\% CI $=1.50$ $2.70), \mathrm{p}=0.029)$. The combined result of the four experiments is represented in Figure 4. In order to validate the results in primary cells we looked at allele specific IFNL3 expression in eight healthy donors heterozygous for the IFNL3.rs4803217 polymorphism. The relative expression levels of the two alleles showed variation between individuals, with ratios of $\mathrm{C}$ to $\mathrm{A}$ allele ranging between 1.4 and 0.7 . Two of the eight donors showed an increased IFNL3.rs4803217 C allele expression. The results were reproducible for each individual. The differences in the ratios did not reach statistical significance (Figure 5). Due to the relatively low expression of the IFNL3 gene in the B cells of uninfected subjects [23], we were unable to measure allele specific IFNL3.rs4803217 expression in their B cells (data not shown)

\section{Discussion}

In order to develop an assay that is able to measure the expressed products of IFNL3 in an allele specific manner, the 3'UTR SNP rs4803217 was chosen, as it is in strong linkage disequilibrium with rs12979860, a predictive marker for the clinical outcome of $\mathrm{HCV}$ infection and treatment response. The assay clearly excludes the amplification of IFNL2 specific sequence as it shows the distinction of three genotypes including AA homozygocity, which would not be possible if the $C$ allele of IFNL2 was present. In addition our assay is also able to discriminate between the two variants of the IFNL3.
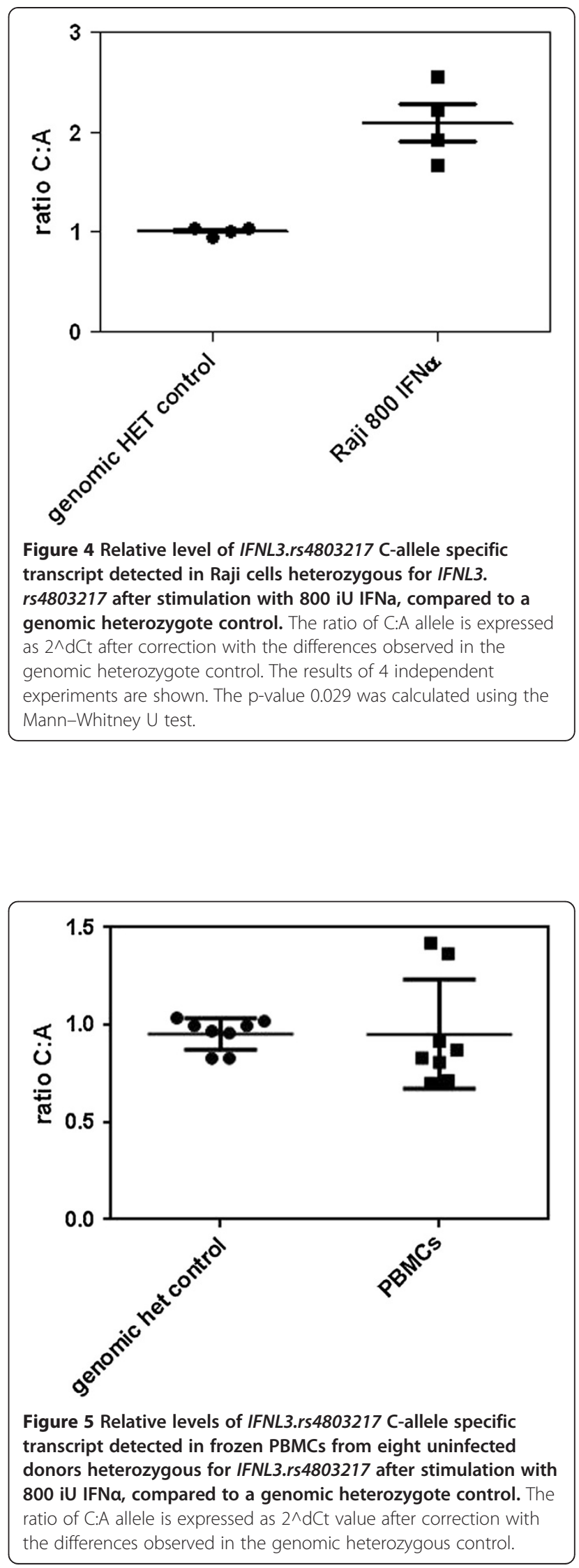
rs4803217 polymorphism. Using this assay we observe increased expression of the IFNL3.rs4803217 C allele in Raji cells at 2 fold level. No difference in the relative level of allele specific expression was observed for Huh7 and Jurkat cells. Raji cells are derived from a B-cell line, where high levels of IFN- $\lambda$ R have been detected, suggesting that B-cells are actively involved in IFNL3 signalling [25]. Raj cells are reported to produce higher levels of IFNL3 compared to Huh7 or Jurkat cell lines [10], which supports the finding that allele specific differences of expression can be context and tissue specific [26]. Unfortunately expression of IFNL3 in the B-cell population of the healthy donors resulted in undetectable levels of IFNL3 due to the low expression of IFNL3 and smaller number of cells available (data not shown).

In order to validate our assay in primary cells, we selected eight uninfected donors heterozygous for $r s 4803217$ and rs12979860. The C allele was up-regulated in two of the eight donors. We detected marked variation in the relative ratio between the $\mathrm{C}$ and $\mathrm{A}$ allele, ranging from 1.4 to 0.7 . Although this variation is not as high as the 2 fold increase as the expression of the $\mathrm{C}$ allele in Raji cells, and not as clear cut as a 1.5 ratio from the standard curve in Figure 2, the ratio was clearly reproducible for each donor.

The C allele of IFNL3.rs4803217 is in LD with the $C$ allele of IFNL3.rs12979860, which is associated with a high frequency of clearance and treatment response. Our results indicate that in certain cells or individuals the $r s 12979860 C C$ and also $C T$ genotype are possibly producing more IFNL3 transcript than the TT genotype, an observation which had been reported earlier using whole blood samples [4], but was not confirmed in liver tissue [8]. In contrast to Suppiah's approach [4] where allele specific variation is measured by comparing IFNL2/3 expression in individuals homozygous for the two alleles of $r s 12979860$, our assay is specific for IFNL3 and is carried out in heterozygotes, so that a comparison of expression between the two alleles within the same cell is less likely to be subject to confounding variables. Our results obtained in eight uninfected healthy donors heterozygous for the IFNL3 SNP rs4803217 (and consequently rs12979860) suggests that variation exists between individuals with regards to allele specific expression. As we only study the differences observed in the allele specific expression of heterozygotes, we cannot exclude that homozygosity of each of the alleles could result in a greater effect of the genotype variation.

Variation in allelic gene expression affects $20-50 \%$ of human genes and may account for variation in the transmission of diseases and disease outcomes [27-29].

It has been reported that differences in allele specific expression are inherited, but that only $3-30 \%$ of individuals exhibit the allele specific expression [27]. It was shown that allelic variation in the adenomatous polyposis coli (APC) gene expression plays a critical role in colon cancer [30]. Variation in allelic expression was also measured for the rs2834167 SNP in IL10RB in Epstein Bar virus (EBV) transformed B-cell line heterozygous for this SNP and might be the underlying functional cause for the association of this SNP with the outcome of HBV infection [31].

In the literature conflicting results are reported with regards to IFNL3 expression in PBMCs versus liver, and differences seem to exist between healthy and chronic donors. In our technical manuscript we use PBMCs of healthy donors to develop the assay as a tool which is able to measure IFNL3 and allele specific expression of IFNL3 transcripts in patient cohorts. A few publications have shown a potential role of blood and immune cells in the recruitment process to the liver during inflammation. Although the expression status of cells might differ between healthy donors and during the process of inflammation, PBMCs are a valid starting point for measuring allele specific expression of IFNL3 [32].

As we did not find consistent up-regulation of the $\mathrm{C}$ allele in eight donors heterozygous for the $\mathrm{C}$ allele of IFNL3.rs4803217 and rs12979860, we investigated the possibility that the observed variation in expression of the $r s 4803217 C$ transcript is influenced by other SNPs in the IFNL3 region. It has been reported that a new variant upstream of the IFNL3 gene, which is in high linkage disequilibrium with rs12979860, and leads to a frameshift mutation creating a new interferon gene IFNL4, might explain the association with the clinical outcomes of $\mathrm{HCV}$ infection [33]. It has been noted that the expression of the IFNL3 gene is dependent on the genotype of the novel ss 469415590 SNP [34]. Genotyping all donors in our study for ss469415590 revealed that they were all heterozygous for ss469415590, thus excluding the possibility of an influence of this variant.

In the three cell lines and eight donors heterozygous for IFNL3.rs4803217 we find 100\% linkage with the IFNL3.rs12979860 marker. High LD between both markers is characteristic for Asian and Caucasian populations [12] (HapMap database $\mathrm{r} 2=0.9$ and $0.7-0.8$ respectively), but reported to be at $\mathrm{r} 2=0.4$ for Sub-Saharan samples. More recently it was shown that the IFNL3. rs4803217 variation seems to affect the stability of the transcript, which could be another way by which the IFNL3 polymorphism exerts its function [35]. Our finding of varying C:A allele expression in certain cells and individuals could be a result of differential stability of the transcript in different individuals. Further studies need to be undertaken to explore the function of the $r s 4803217$ polymorphism in the outcome of $\mathrm{HCV}$ infection and treatment response, using an IFNL3 and allele specific assay for $r s 4803217$. 


\section{Conclusion}

In conclusion, we show that the allele specific assay for IFNL3 which we developed is a useful tool to determine the IFNL3.rs4803217 genotype and at the same time accurately and directly compare the expression of two alleles of the IFNL3 gene within heterozygous cells. As the rs4803217 SNP has been reported to have an effect on the stability of the transcript [35] the developed assay could be used for the measurement of allele specific IFNL3 expression in patient groups with different $\mathrm{HCV}$ outcomes and treatment response, to determine the clinical relevance of the observed variation.

\section{Additional files}

Additional file 1: Figure S1. Sequences of amplification products of IFNL3 allele specific rs4803217 assay. A: The products are IFNL3 specific at position 11 from the 5'end of the forward primer (starting from GCT; $A$ is not part of the primer sequence), where IFNL3 is characterized by a T(A) allele, whereas IFNL2 has a C(G) allele. The T(A) specific primer amplified the TT(AA) homozygote, whereas the $C(G)$ specific primers amplified the GG (CC) homozygote. $5^{\prime}$ and $3^{\prime}$ describe the direction of the primer extension during the amplification.

Additional file 2: Figure S2. Induction of OAS and IFNL2/3 by $800 i U$ IFNa after 3, 6, 8, 12 and 24 hours.

\section{Competing interests}

The authors declare that they have no competing interests.

\section{Authors' contribution}

The project (assay design, validation, cell culture and quantitative RT-PCR, writing of manuscript and preparation of figures) was carried out by SK. NM helped with the setting up of dose response curves under the supervision of SK. SC and KJ have collected and prepared the PBMCs of the uninfected donors. The funders had no role in study design, data collection and analysis, decision to publish, or preparation of the manuscript. All authors read and approved the final manuscript.

\section{Acknowledgements}

The authors acknowledge funding by the EU framework seven (FP7) grant 260844 awarded to MT. SK was funded by the EU framework seven (FP7) grant 260844. NM was a BSC student at the time of the conception of the project. SC and KJ were supported by the Wellcome Trust. All authors acknowledge support from the Imperial College Biomedical Research Centre. The authors thank Dr Marco Purbhoo for making available the Huh7, Raji and Jurkat cell lines.

Received: 23 August 2013 Accepted: 5 September 2014

Published online: 05 October 2014

\section{References}

1. Ge D, Fellay J, Thompson AJ, Simon JS, Shianna KV, Urban TJ, Heinzen EL, Qiu P, Bertelsen AH, Muir AJ, Sulkowski M, McHutchison JG, Goldstein DB: Genetic variation in IL28B predicts hepatitis $C$ treatment-induced viral clearance. Nature 2009, 461(7262):399-401.

2. Thomas DL, Thio CL, Martin MP, Qi Y, Ge D, O'Huigin C, Kidd J, Kidd K, Khakoo SI, Alexander G, Goedert JJ, Kirk GD, Donfield SM, Rosen HR, Tobler LH, Busch MP, McHutchison JG, Goldstein DB, Carrington M: Genetic variation in IL28B and spontaneous clearance of hepatitis C virus. Nature 2009, 461(7265):798-801.

3. Tanaka Y, Nishida N, Sugiyama M, Kurosaki M, Matsuura K, Sakamoto N, Nakagawa M, Korenaga M, Hino K, Hige S, Ito Y, Mita E, Tanaka E, Mochida S, Murawaki Y, Honda M, Sakai A, Hiasa Y, Nishiguchi S, Koike A, Sakaida I, Imamura M, Ito K, Yano K, Masaki N, Sugauchi F, Izumi N, Tokunaga K, Mizokami M: Genome-wide association of IL28B with response to pegylated interferon-alpha and ribavirin therapy for chronic hepatitis $C$. Nat Genet 2009, 41(10):1105-9.

4. Suppiah V, Moldovan M, Ahlenstiel G, Berg T, Weltman M, Abate ML, Bassendine M, Spengler U, Dore GJ, Powell E, Riordan S, Sheridan D, Smedile A, Fragomeli V, Müller T, Bahlo M, Stewart GJ, Booth DR, George J: IL28B is associated with response to chronic hepatitis $C$ interferon-alpha and ribavirin therapy. Nat Genet 2009, 41(10):1100-4.

5. Rauch A, Kutalik Z, Descombes P, Cai T, Di IJ, Mueller T, Bochud M, Battegay M, Bernasconi E, Borovicka J, Colombo S, Cerny A, Dufour JF, Furrer H, Günthard HF, Heim M, Hirschel B, Malinverni R, Moradpour D, Müllhaupt B, Witteck A, Beckmann JS, Berg T, Bergmann S, Negro F, Telenti A Bochud PY, Swiss Hepatitis C Cohort Study, Swiss HIV Cohort Study: Genetic variation in IL28B is associated with chronic hepatitis C and treatment failure: a genome-wide association study. Gastroenterology 2010, 138(4):1338-45. 1345.

6. Pedergnana V, Abdel-Hamid M, Guergnon J, Mohsen A, Le Fouler L, Theodorou I, Mohamed MK, Fontanet A, Plancoulaine S, Abel L: Analysis of IL28B variants in an Egyptian population defines the 20 kilobases minimal region involved in spontaneous clearance of hepatitis $C$ virus. PLoS One 2012, 7(6):e38578.

7. Abe H, Hayes CN, Ochi H, Maekawa T, Tsuge M, Miki D, Mitsui F, Hiraga N, Imamura M, Takahashi S, Kubo M, Nakamura Y, Chayama K, Mitsui F, Hiraga N, Imamura M, Takahashi S, Kubo M, Nakamura Y, Chayama K: IL28 variation affects expression of interferon stimulated genes and peg-interferon and ribavirin therapy. J Hepatol 2011, 54(6):1094-101.

8. Urban TJ, Thompson AJ, Bradrick SS, Fellay J, Schuppan D, Cronin KD, Hong L, McKenzie A, Patel K, Shianna KV, McHutchison JG, Goldstein DB, Afdhal N: IL28B genotype is associated with differential expression of intrahepatic interferon-stimulated genes in patients with chronic hepatitis $C$. Hepatology 2010, 52(6):1888-96.

9. Ito K, Higami K, Masaki N, Sugiyama M, Mukaide M, Saito H, Aoki Y, Sato Y, Imamura M, Murata K, Nomura H, Hige S, Adachi H, Hino K, Yatsuhashi H, Orito E, Kani S, Tanaka Y, Mizokami M: The rs8099917 polymorphism, when determined by a suitable genotyping method, is a better predictor for response to pegylated alpha interferon/ribavirin therapy in Japanese patients than other single nucleotide polymorphisms associated with interleukin-28B. J Clin Microbiol 2011, 49(5):1853-60.

10. Sugiyama M, Kimura T, Naito S, Mukaide M, Shinauchi T, Ueno M, Ito K, Murata K, Mizokami M: Development of specific and quantitative real-time detection PCR and immunoassays for $\lambda$ 3-interferon. Hepatol Res 2012, 42(11):1089-99. doi:10.1111/j.1872-034X.2012.01032.x. Epub 2012 Jun 5.

11. De Castellarnau M, Aparicio E, Parera M, Franco S, Tural C, Clotet B, Martinez MA: Deciphering the interleukin $28 \mathrm{~B}$ variants that better predict response to pegylated interferon-alpha and ribavirin therapy in HCV/HIV-1 coinfected patients. PloS One 2012, 7(2):e31016.

12. Smith KR, Suppiah V, O'Connor K, Berg T, Weltman M, Abate ML, Spengler U, Bassendine M, Matthews G, Irving WL, Powell E, Riordan S, Ahlenstiel G, Stewart GJ, Bahlo M, George J, Booth DR, International Hepatitis C Genetics Consortium (IHCGC): Identification of improved IL28B SNPs and haplotypes for prediction of drug response in treatment of hepatitis $C$ using massively parallel sequencing in a cross-sectional European cohort. Genome Med 2011, 3(8):57.

13. Germer S, Holland MJ, Higuchi R: High-throughput SNP allele-frequency determination in pooled DNA samples by kinetic PCR. Genome Res 2000 , 10(2):258-66.

14. Nakabayashi H, Taketa K, Miyano K, Yamane T, Sato J: Growth of human hepatoma cells lines with differentiated functions in chemically defined medium. Cancer Res 1982, 42(9):3858-63.

15. Drexler HG, Minowada J: History and classification of human leukemia-lymphoma cell lines. Leuk Lymphoma 1998, 31(3-4):305-16.

16. Schneider U, Schwenk HU, Bornkamm G: Characterization of EBV-genome negative "null" and "T" cell lines derived from children with acute lymphoblastic leukemia and leukemic transformed non-Hodgkin lymphoma. Int J Cancer 1977, 19(5):621-6.

17. Zhao $L$, Hua X, He SF, Ren H, Qi ZT: Interferon alpha regulates MAPK and STAT1 pathways in human hepatoma cells. Virol J 2011, 8:157.

18. Pedersen IM, Cheng G, Wieland S, Volinia S, Croce CM, Chisari FV, David M: Interferon modulation of cellular microRNAs as an antiviral mechanism. Nature 2007, 449(7164):919-22.

19. Shin EC, Seifert U, Kato T, Rice CM, Feinstone SM, Kloetzel PM, Rehermann B: Virus-induced type I IFN stimulates generation of immunoproteasomes at the site of infection. J Clin Invest 2006, 116(11):3006-14. 
20. Zhang L, Jilg N, Shao RX, Lin W, Fusco DN, Zhao H, Goto K, Peng LF, Chen WC, Chung RT: IL28B inhibits hepatitis C virus replication through the JAK-STAT pathway. J Hepatol 2011, 55(2):289-98.

21. Gondois-Rey F, Dental C, Halfon P, Baumert TF, Olive D, Hirsch I: Hepatitis C virus is a weak inducer of interferon alpha in plasmacytoid dendritic cells in comparison with influenza and human herpesvirus type- 1 . Plos One 2009, 4(2):e4319.

22. Helbig KJ, Ruszkiewicz A, Semendric L, Harley HA, McColl SR, Beard MR: Expression of the CXCR3 ligand I-TAC by hepatocytes in chronic hepatitis $C$ and its correlation with hepatic inflammation. Hepatology 2004, 39(5):1220-9.

23. Diegelmann J, Beigel F, Zitzmann K, Kaul A, Goke B, Auernhammer CJ, Bartenschlager R, Diepolder HM, Brand S: Comparative analysis of the lambda-interferons IL-28A and IL-29 regarding their transcriptome and their antiviral properties against hepatitis C virus. PLoS One 2010, 5(12):e15200.

24. Knapp S, Warshow U, Ho KM, Hegazy D, Little AM, Fowell A, Alexander G, Thursz M, Cramp M, Khakoo Sl: A polymorphism in IL28B distinguishes exposed, uninfected individuals from spontaneous resolvers of HCV infection. Gastroenterology 2011, 141(1):320-5. 325.

25. Witte K, Gruetz G, Volk HD, Looman AC, Asadullah K, Sterry W, Sabat R, Wolk K: Despite IFN-lambda receptor expression, blood immune cells, but not keratinocytes or melanocytes, have an impaired response to type III interferons: implications for therapeutic applications of these cytokines. Genes Immun 2009, 10(8):702-14.

26. Knight JC, Keating BJ, Rockett KA, Kwiatkowski DP: In vivo characterization of regulatory polymorphisms by allele-specific quantification of RNA polymerase loading. Nat Genet 2003, 33(4):469-75.

27. Yan H, Yuan W, Velculescu VE, Vogelstein B, Kinzler KW: Allelic variation in human gene expression. Science 2002, 297(5584):1143.

28. Lo HS, Wang Z, Hu Y, Yang HH, Gere S, Buetow KH, Lee MP: Allelic variation in gene expression is common in the human genome. Genome Res 2003, 13(8):1855-62.

29. Grievink H, Stowell KM: Allele-specific differences in ryanodine receptor 1 mRNA expression levels may contribute to phenotypic variability in malignant hyperthermia. Orphanet J Rare Dis 2010, 5:10.

30. Yan H, Dobbie Z, Gruber SB, Markowitz S, Romans K, Giardiello FM, Kinzler KW, Vogelstein B: Small changes in expression affect predisposition to tumorigenesis. Nat Genet 2002, 30(1):25-6

31. Frodsham AJ, Zhang L, Dumpis U, Taib NA, Best S, Durham A, Hennig BJ, Hellier S, Knapp S, Wright M, Chiaramonte M, Bell Jl, Graves M, Whittle HC, Thomas HC, Thursz MR, Hill AV, Hennig BJ, Hellier S, Knapp S, Wright M, Chiaramonte M, Bell Il, Graves M, Whittle HC, Thomas HC, Thursz MR, Hill AV: Class II cytokine receptor gene cluster is a major locus for hepatitis B persistence. Proc Natl Acad Sci U S A 2006, 103(24):9148-53.

32. Accapezzato D, Francavilla V, Paroli M, Casciaro M, Chircu LV, Cividini A, Abrignani S, Mondelli MU, Barnaba V: Hepatic expansion of a virus-specific regulatory $\mathrm{CD} 8(+) \mathrm{T}$ cell population in chronic hepatitis $\mathrm{C}$ virus infection. J Clin Invest 2004, 113(7):963-72.

33. Prokunina-Olsson L, Muchmore B, Tang W, Pfeiffer RM, Park H, Dickensheets H, Hergott D, Porter-Gill P, Mumy A, Kohaar I, Chen S, Brand N, Tarway M, Liu L, Sheikh F, Astemborski J, Bonkovsky HL, Edlin BR, Howell CD, Morgan TR, Thomas DL, Rehermann B, Donnelly RP, O'Brien TR: A variant upstream of IFNL3 (IL28B) creating a new interferon gene IFNL4 is associated with impaired clearance of hepatitis C virus. Nat Genet 2013, 45(2):164-71.

34. Bibert S, Roger T, Calandra T, Bochud M, Cerny A, Semmo N, Duong FH, Gerlach T, Malinverni R, Moradpour D, Negro F, Müllhaupt B, Bochud PY, Swiss Hepatitis C Cohort Study: IL28B expression depends on a novel TT/-G polymorphism which improves HCV clearance prediction. J Exp Med 2013, 210(6):1109-16.

35. McFarland AP, Horner SM, Jarret A, Joslyn RC, Bindewald E, Shapiro BA, Delker DA, Hagedorn CH, Carrington M, Gale M Jr, Savan R: The favorable IFNL3 genotype escapes mRNA decay mediated by AU-rich elements and hepatitis C virus-induced microRNAs. Nat Immunol. 2014, 15(1):72-9. doi: 10.1038/ni.2758. Epub 2013 Nov 17.

doi:10.1186/s12881-014-0104-7

Cite this article as: Knapp et al:: Detection of allele specific differences

in IFNL3 (IL28B) mRNA expression. BMC Medical Genetics 2014 15:104.

\section{Submit your next manuscript to BioMed Central and take full advantage of:}

- Convenient online submission

- Thorough peer review

- No space constraints or color figure charges

- Immediate publication on acceptance

- Inclusion in PubMed, CAS, Scopus and Google Scholar

- Research which is freely available for redistribution

Submit your manuscript at www.biomedcentral.com/submit
() Biomed Central 